\title{
An Evaluation of Immune-Profile and IgE Binding Proteins in the Sera of Respiratory Allergy Patients of North India to Commonly Consumed Foods
}

\author{
Chandni Mathur ${ }^{1}$, Pooran Chand Kathuria ${ }^{2}$, Pushpa Dahiya ${ }^{3}$ and Anand Bahadur Singh ${ }^{4 *}$ \\ ${ }^{1}$ Allergy \& Aerobiology Division, CSIR-Institute of Genomics \& Integrative Biology, Delhi, India \\ ${ }^{2}$ National Allergy Centre, East Patel Nagar, Delhi, India \\ ${ }^{3}$ Department of Botany, Maharishi Dayanand University, Rohtak, India \\ ${ }^{4}$ Director Training, National Allergy Centre, Delhi, India
}

Submission: April 01, 2019; Published: April 23, 2019

*Corresponding author: Anand Bahadur Singh, Director Training, National Allergy Centre, Delhi, India

Abstract

Background: Total and allergen specific Immunoglobulin E (IgE) in the sera are considered diagnostic markers of atopy and allergy. Prevalence of food sensitization in patients of respiratory allergy in India are reported to be limited based on measurements of food specific IgE (sIgE)

The aim of this study was to screen total serum IgE and food specific IgE levels against commonly consumed foods in respiratory allergy patients of North India for assessing food sensitization pattern and their Immuno-reactive antigen profile.

Methods: A total of 252 patients of respiratory allergy and 29, healthy control subjects participated in the study. Total serum IgE and food sIgE against peanut, soybean, chickpea, maize and rice were estimated in patients and control group by Enzyme Linked Immunosorbent Assay (ELISA). Protein profiling and Immunoblotting was employed to study the IgE binding protein epitopes in IgE sensitized patients.

Results: Mean total IgE level in symptomatic group was significantly higher than the control group ( $p<0.001)$. Likewise, mean total IgE level $(\mathrm{IU} / \mathrm{ml})$ was recorded to be significantly higher $(\mathrm{p}<0.05)$ in asthmatics than in patients with Allergic Rhinitis (AR) and Allergic Rhinitis with Bronchial Asthma (AR+BA) groups. Elevated serum IgE levels appear to be associated with males and younger age groups than in adults. The prevalence of food sensitization based on sIgE to respective foods in respiratory allergy patients is recorded to be $17 \%$ with cereals and legumes.

Conclusion: Prevalence of food sensitization in North Indian patients is indicated to be $17 \%$ with cereal and legumes studied. Atopy, asthma and elevated serum IgE levels are observed to be partially associated factors for food sensitization.

Keywords: Serum IgE; Respiratory Tract; Food Allergy; India

Abbreviation: IgE: Immunoglobulin E; ELISA: Enzyme Linked Immunosorbent Assay; AR: Allergic Rhinitis; BA: Bronchial Asthma; SPT: Skin Prick Test; HRP: Horse Radish Peroxidase; ANOVA: Analysis of Variance

\section{Introduction}

Allergy is defined as an exaggerated response of the immune system typified by immunoglobulin E (IgE) levels against the offending substance called 'allergen' [1]. Allergic diseases include asthma, rhinitis, conjunctivitis, angioedema, food allergies, urticaria, eczema and even life-threatening anaphylaxis. As per World Health Organization (WHO) reports, the number of patients having asthma is 300 million and is expected to increase to 400 million by 2025 [2]. The total immunoglobulin E (IgE) level comprising of the cell bound as well as circulating IgE antibodies form a clinical marker for allergy diagnosis, while allergen specific IgE (sIgE) is a positive indicator of sensitization $[3,4]$. Elevated total IgE levels are generally indicative of atopy

but many clinically proven allergic individuals may have normal total serum IgE levels [5]. A number of epidemiological studies have shown a strong association between total serum IgE levels, skin prick test or specific IgE positivity to aeroallergens and asthma phenotype $[6,7,8]$. Food allergy, one of the important allergic diseases is on a rise worldwide, affecting nearly $10 \%$ of the population [8,9]. More than 170 foods have been reported to cause IgE-mediated reactions, with big eight foods- peanut, tree nuts, egg, milk, fish, crustacean shellfish, wheat, and soy being attributed as "major food allergens" [9].

Questionnaire-based estimates tend to overestimate the real rate of food allergy, whereas the "gold standard," food challenge, 
is logistically difficult and sometimes unethical and may lead to anaphylaxis [10]. Determination of the true prevalence of food sensitization/allergy is still challenging and difficult to correlate with other factors as total serum IgE, food specific IgE (sIgE), Skin Prick Test (SPT) and a good clinical history. Sporadic studies focused on Indian patients have highlighted for self-history based food sensitization pattern to be as high as $58-70 \%[11,12]$. The present study is aimed at to find food hypersensitivity pattern due to five commonly consumed foods by screening for food specific IgE and IgE binding protein profiles in the sera of respiratory allergy patients from North India beside total serum IgE.

\section{Materials and Methods}

\section{Selection of Foods}

The Indian food diet comprises variety of cereals and legumes. Knowledge about prevalence of food sensitization among commonly consumed foods in Indians is still limited. Keeping this in mind, five different foods comprising cereals as maize and rice, and legumes namely peanut, chickpea and soybean, being commonly consumed in India were selected for the present study.

\section{Preparation of Food Antigen Extracts}

Healthy seeds of selected five foods procured from the market were crushed to fine powder and defatted in diethyl ether at $4{ }^{\circ} \mathrm{C}$. The antigens were extracted from defatted seed powder in 1:20 (w/v) ammonium bicarbonate buffer (50 mM, $\mathrm{pH}$ 8.0) with $5 \mathrm{mM}$ ethylene diamine tetra acetate and $1 \mathrm{mM}$ phenyl methyl sulfonyl fluoride by continuous stirring for 6-8hrs at $4{ }^{\circ} \mathrm{C}$ [13]. The suspension was centrifuged at $12,000 \mathrm{rpm}$ for $20 \mathrm{~min}$ at $4{ }^{\circ} \mathrm{C}$. The filtrate obtained was passed through a 0.45 $\mu \mathrm{m}$ nitrocellulose filter membrane, aliquoted in small quantities, lyophilized and stored at $-70^{\circ} \mathrm{C}$ for further experimentation and assays.

\section{Selection of Patients and Healthy Controls}

A total of 252 patients with respiratory disorders visiting two allergy clinics in North India for treatment were enrolled in the present study. The physician diagnosis of asthma and rhinitis in participants was ascertained following international medical guidelines $[14,15]$. Detailed clinical history and medication history, information related to allergy symptoms and allergic reactions to any suspected food (in addition to five food antigens of our panel) was recorded. The study also included 29 normal healthy control subjects with no history of allergy. The study protocol was approved by Institutional Human Ethics Committee.

\section{Blood Collection}

Consent form was administered to all enrolled participants for collection of $10 \mathrm{ml}$ venous blood samples. After collection of blood, it was allowed to clot, and separated sera was clarified by centrifugation and stored at $-70^{\circ} \mathrm{C}$ for further experimentation in small aliquots.

\section{Total Serum Immunoglobulin E}

Total serum IgE of allergic patients was measured using sandwich ELISA technique. Monoclonal anti-human-IgE antibody (Bethyl Laboratories Inc., Texas, USA) was coated onto a 96-well polypropylene ELISA plate (Nunc Maxisorp, A/S Rocskilde, Denmark) and incubated overnight at $4{ }^{\circ} \mathrm{C}$. IgE calibrators and serum samples diluted to $1: 10$ were added to the wells on second day and incubated overnight at $4{ }^{\circ} \mathrm{C}$. Next day, after repeated washings, detection antibody anti-human IgE conjugated to HRP (diluted 1: 10 000) was added to the plates and incubated at room temperature for $3 \mathrm{~h}$. The colour was developed with ABTS (azino bis tetra sulphonic acid), and optical density (OD) was measured at 405nm using an ELISA Reader (Bio-Rad Laboratories, Inc., CA, USA). A standard curve was generated using IgE calibrators and was plotted on a LinLog graph. All serum samples were run in duplicate and the mean of the same was taken for further statistical analysis. All values are expressed in $\mathrm{IU} / \mathrm{mL}(1 \mathrm{IU} / \mathrm{mL}=2.4 \mathrm{ng} / \mathrm{mL})$.

\section{Food specific Immunoglobulin E}

Food specific IgE against in house food extracts - Peanut, Soybean, Chickpea, Maize and Rice were measured in sera of enrolled allergic subjects by indirect ELISA according to the method outlined by Sepulveda and group [16]. Briefly food extract(s) in carbonate buffer $(0.2 \mu \mathrm{g} / 100 \mu \mathrm{l}$ per well), was coated on a microtiter plate (Nunc, USA) and incubated overnight at $4{ }^{\circ} \mathrm{C}$. After washing with phosphate buffer saline (PBS), the nonspecific sites were blocked with $1 \%$ Non-fat dry milk for 2 hr. at $37^{\circ} \mathrm{C}$. The plate was washed with PBS and incubated with $1: 10 \mathrm{v} / \mathrm{v}$ diluted sera of patient(s), overnight at $4{ }^{\circ} \mathrm{C}$. Healthy non-allergic human sera samples were used as control. On third day, the plate was washed with phosphate buffer saline-Tween 20 (PBST) and incubated with antihuman IgE-horse radish peroxidase (1:1000 v/v; Southern Biotech, USA) in 0.05\% nonfat dry milk in PBST for $1 \mathrm{hr}$. at $37^{\circ} \mathrm{C}$. Colour was developed with orthophenylene diamine. The reaction was stopped by adding $2.5 \mathrm{M} \mathrm{H}_{2} \mathrm{SO}_{4}$ and the absorbance was read at $492 \mathrm{~nm}$.

\section{Sodium Dodecyl Sulphate-Polyacrylamide Electrophoresis (SDS-PAGE)}

The protein profile of different food antigens (water soluble) was elucidated using SDS-PAGE, as per the procedure outlined by Laemmli [17]. A $12 \%$ polyacrylamide gel containing $0.1 \%$ SDS as separating gel and a $4 \%$ polyacrylamide gel as stacking gel in combination with tris glycine buffer was used in Mini Electrophoretic Apparatus (BIO-RAD Inc.). The food antigen(s) before loading were heated with $5 \mathrm{X}$ sample buffer ( $2 \%$ SDS, $10 \%$ glycerol, $5 \%$ ß-Mercaptoehanol, $0.01 \mathrm{M}$ Tris pH 8.0, $0.001 \mathrm{M}$ EDTA and $0.1 \%$ Bromophenol dye) for $5 \mathrm{~min}$ at $100{ }^{\circ} \mathrm{C}$. Electrophoresis was carried out at voltage of $80 \mathrm{~V}$ initially and increased to $100 \mathrm{~V}$ till completion. Standard proteins molecular weight marker was also loaded along with the samples. The gel was stained in Coomassie Brilliant Blue (CBB) staining solution for $1 \mathrm{hr}$ and then de-stained in solution consisting Methanol; 
T/D/W and Acetic acid in the ratio of 40: 50: 10, for scanning and further analysis.

\section{Immunoblot}

The SDS resolved proteins of food extracts were transferred on to nitrocellulose membrane (NCM) as described [18]. The unbound sites were blocked by $3 \%$ Nonfat dry milk for $3 \mathrm{hr}$ at $37{ }^{\circ} \mathrm{C}$. The NCM strips were washed and incubated with 1:10 v/v food allergic sera at $4{ }^{\circ} \mathrm{C}$, overnight. Healthy serum pool was taken as control. The strips were washed with PBST and incubated with 1:1000 diluted antihuman IgE-peroxidase for $1 \mathrm{hr}$. The IgE binding was detected by diaminobenzidine (DAB) with hydrogen peroxide in sodium acetate buffer ( $\mathrm{pH}$ 5.0). The detection was finally stopped using $0.2 \mathrm{~N} \mathrm{HCl}$.

\section{Statistical Analysis}

The statistical analysis was carried out using the MS EXCEL, Prism V software (Graph Pad Prism, San Diego, California, USA. Values of IgE measurements are represented as mean \pm standard error mean. The variation of total serum IgE based on gender amongst the three disease groups was analyzed by student $t$-test (two-tailed). The extent of association of age with IgE was analyzed as a correlation function and the variation was estimated by ANOVA. Comparison of mean values involving more than two groups, was conducted by ANOVA. The significance level as observed by student $t$-test or ANOVA was considered to be at $\mathrm{p}$ value $\leq 0.05$. The cutoff point to define ELISA positive cases was absorbance / Optical Density (OD492) $\geq 3$ times the value of healthy volunteers [19] in each of the respective cases.

Results

\section{Demographic and Clinical Profile of Respiratory Allergy patients}

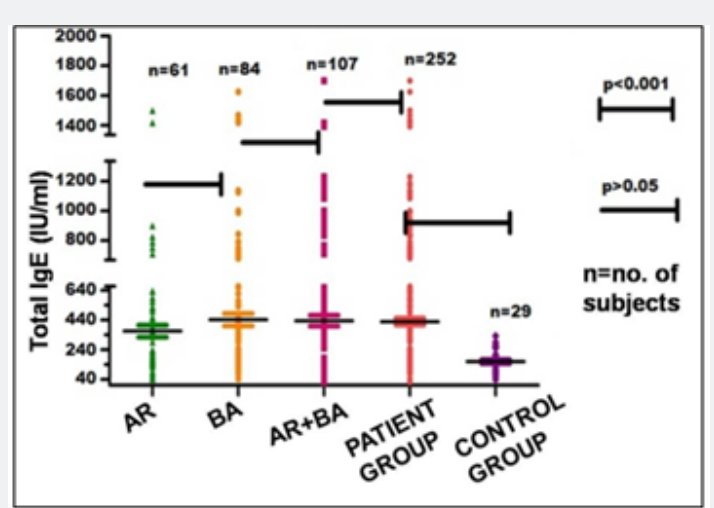

Figure 1: Correlation between Total Serum IgE levels (IU/ml) observed in different diseased groups - Allergic Rhinitis (AR), Bronchial Asthma (BA) and combined group of AR+BA. Control group represents healthy volunteers.

The age of enrolled 252 patients varied from 5 - 60 (yrs.) with the mean age as $32.3 \pm 2$ (yrs.) Male and female patients accounted $52 \%$ and $48 \%$, respectively (Table 1). The number of participants suffering from allergic rhinitis (AR) with bronchial asthma (BA) accounted as107 (43\%), followed by 84 (33\%) of bronchial asthma and 61 cases (24\%) with allergic rhinitis. With respect to healthy volunteers, a mean age of $25.8 \pm 1.0$ (yrs.) with male subjects accounting for 19 cases (65\%) was recorded (Figure 1).

Table 1: Demographic profile of allergy patients and control subjects from two allergy clinics of North India.

\begin{tabular}{|c|c|c|}
\hline & Patient Group & Control Group \\
\hline $\begin{array}{c}\text { Total No. of cases } \\
\text { Mean age } \pm \text { SEM } \\
\text { (yrs.) }\end{array}$ & 252 & 29 \\
\hline Age Group (yrs.) & No. of Male/ Female & No. of Male/ Female \\
\hline $5-12$ & $17 / 9$ & 0 \\
\hline $13-20$ & $17 / 15$ & $1 / 0$ \\
\hline $21-30$ & $22 / 31$ & $15 / 10$ \\
\hline $31-40$ & $31 / 27$ & $2 / 0$ \\
\hline $41-50$ & $23 / 22$ & 0 \\
\hline $51-60$ & $22 / 16$ & 1 \\
\hline Total & $\begin{array}{c}\text { Male- } 132(52 \%) \\
\text { Female- } 120(48 \%)\end{array}$ & $\begin{array}{c}\text { Male }-19(65 \%) \\
\text { Female }-10(35 \%)\end{array}$ \\
\hline
\end{tabular}

Total Serum IgE level in Allergy Patients and Healthy Controls

In the symptomatic group, serum IgE level ranged from 20 $1700 \mathrm{IU} / \mathrm{ml}$ with a mean value of $423 \mathrm{IU} / \mathrm{ml}$. In case of control group, it ranged from $37.5-333 \mathrm{IU} / \mathrm{ml}$ with a mean value of 159 $\mathrm{IU} / \mathrm{ml}$. In AR patients, total serum IgE ranged from 41-1500 IU/ $\mathrm{ml}$ with mean value of $377 \mathrm{IU} / \mathrm{ml}$. In cases of bronchial asthma patients, it varied from $42-1625 \mathrm{IU} / \mathrm{ml}$ with mean value of 442 $\mathrm{IU} / \mathrm{ml}$. In the patients of allergic rhinitis with BA, it ranged from $20-1700$ with a mean value $438 \mathrm{IU} / \mathrm{ml}$.

\section{Total serum IgE in Symptomatic Groups and Control Subjects based on Gender}

The mean total serum IgE levels recorded in different symptomatic group based on gender is provided in Table 2 . Males of the entire symptomatic group had higher mean total $\operatorname{IgE}(431 \mathrm{IU} / \mathrm{ml})$ than females $(383 \mathrm{IU} / \mathrm{ml})$, but this difference is not significant $(p>0.05)$. While vice versa is observed in case of control group, with female subjects exhibiting higher mean IgE level $(170 \mathrm{IU} / \mathrm{ml})$ as against male subjects $(153 \mathrm{IU} / \mathrm{ml})$. The mean IgE level recorded in male patients with allergic rhinitis and bronchial asthma $(\mathrm{AR}+\mathrm{BA})$ was $(434 \mathrm{IU} / \mathrm{ml})$ while in bronchial asthma alone it was $440 \mathrm{IU} / \mathrm{ml}$, reflecting a nearly similar level. A relatively lower IgE level (417 IU/ml) was observed in Allergic rhinitis group. In case of, female patients, the mean total IgE level varied in the ascending order as $317,400,432 \mathrm{IU} / \mathrm{ml}$ in the $\mathrm{AR}, \mathrm{AR}+\mathrm{BA}$ and $\mathrm{BA}$ groups respectively. Thus, the intra disease groups variation, of mean total IgE in both genders appears to be statistically not significant $(\mathrm{p}>0.05)$.

\section{Total Serum IgE in different Age groups of Symptomatic}

All the patients were divided in six age groups on the basis of age as depicted in Figure 2. Among the six age groups, highest 


\section{Global Journal of Otolaryngology}

mean total serum IgE (486 IU/ml) is observed in youngest correlation ( $\mathrm{r} 2=-0.01, \mathrm{p}>0.05)$ is observed between increasing age groups of 5-12 yrs. while lowest (382 IU/ml) is observed age and total IgE levels, signifying that total serum IgE decreases in the elderly group of $51-60$ years. A linear nonsignificant gradually with increasing age of atopic subjects.

Table 2: Analysis of patients on the basis of gender under different symptomatic groups.

\begin{tabular}{|c|c|c|c|c|c|c|c|c|}
\hline & \multicolumn{6}{|c|}{$\begin{array}{c}\text { Diseased Group } \\
\text { Total Cases N = 252 }\end{array}$} & \multirow{2}{*}{\multicolumn{2}{|c|}{$\begin{array}{c}\text { Control } \\
\text { Group } N=29\end{array}$}} \\
\hline & \multicolumn{2}{|c|}{ *AR } & \multicolumn{2}{|c|}{$\dagger \mathbf{B A}$} & \multicolumn{2}{|c|}{$\mathrm{BA}+\mathrm{AR}$} & & \\
\hline & No. & $\%$ & No. & $\%$ & No. & $\%$ & \multirow{2}{*}{ No. } & \multirow{2}{*}{$\%$} \\
\hline Total No. of Cases & 61 & $(24)$ & 84 & (33) & 107 & $(43)$ & & \\
\hline No. of Male $\mathrm{c}$ ases & 36 & $(59)$ & 49 & $(58)$ & 47 & $(52)$ & 19 & $(65)$ \\
\hline Mean Total IgE (IU/ml) in male group under specified class & \multicolumn{2}{|c|}{417} & \multicolumn{2}{|c|}{440} & \multicolumn{2}{|c|}{437} & \multicolumn{2}{|c|}{153} \\
\hline No. of Female cases & 25 & $(40)$ & 35 & $(42)$ & 60 & $(56)$ & 10 & (35) \\
\hline Mean Total IgE (IU/ml) in female group under specified class & \multicolumn{2}{|c|}{317} & \multicolumn{2}{|c|}{432} & \multicolumn{2}{|c|}{400} & \multicolumn{2}{|c|}{170} \\
\hline
\end{tabular}

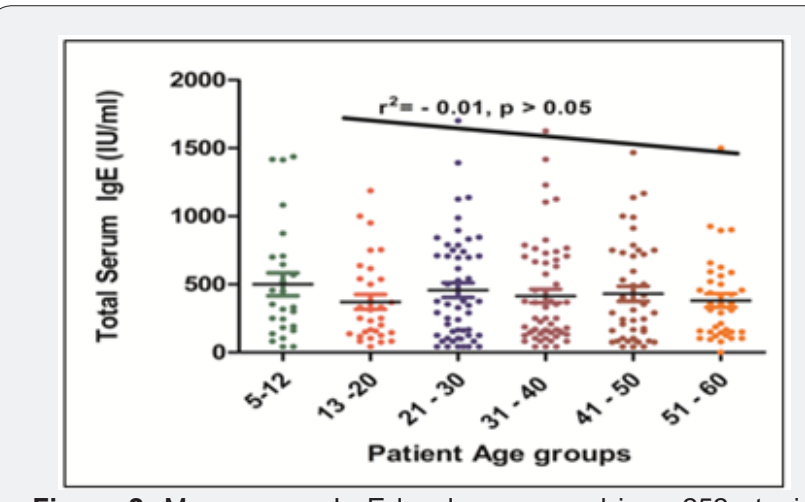

Figure 2: Mean serum Ig $E$ levels expressed in $n=252$ atopic patients categorized under six different age groups. (1)5 - 12 years : (486 IU/ml); (2) 13-20 years: (365 IU/ml); (3) 21-30 years: $(452 \mathrm{IU} / \mathrm{ml}) \quad$ (4) 31 - 40 years: $(414 \mathrm{IU} / \mathrm{ml})$ (5) 41 - 50 years: $(430 \mathrm{IU} / \mathrm{ml})(6) 51-60$ years: $(382 \mathrm{IU} / \mathrm{ml})$.

\section{Prevalence of Food specific IgE in Respiratory allergic patients of North India}

The sera samples obtained from the respiratory allergic patients and control subjects were analyzed for specific IgE Table 3: Mean Specific IgE of control subjects against food antigens for estimation of food sensitized patients.

\begin{tabular}{|c|c|c|c|c|}
\hline Food Antigen & $\begin{array}{l}\text { (A) Mean sIgE OD value } \\
\text { of } 29 \text { control subjects }\end{array}$ & $\begin{array}{l}\text { (B) Cutoff Point to define positive } \\
\text { cases, }=3^{*} \text { Mean OD value (A) }\end{array}$ & $\begin{array}{l}\text { (C) No. of sIgE positive cases } \\
\text { with OD values > cut off point }\end{array}$ & $\begin{array}{l}\text { \%Food Sensitization } \\
\quad=\mathrm{C} / 252 * 100\end{array}$ \\
\hline Peanut & 0.042 & 0.126 & 12 & 4.8 \\
\hline Soybean & 0.045 & 0.135 & 10 & 4.0 \\
\hline Chickpea & 0.04 & 0.12 & 14 & 5.6 \\
\hline Maize & 0.027 & 0.081 & 14 & 5.6 \\
\hline Rice & 0.04 & 0.12 & 10 & 4.0 \\
\hline $\begin{array}{l}\text { Total No of food } \\
\text { positive cases }\end{array}$ & & & 60 & \\
\hline
\end{tabular}

Supplementary Table 1: Clinico-Immuno details of 44 cases showing raised food specific IgE against tested five food antigens.

\begin{tabular}{|c|c|c|c|c|c|}
\hline $\begin{array}{c}\text { Patient } \\
\text { No. }\end{array}$ & Age & Sex & $\begin{array}{c}\text { Diagnosis BA-Bronchial Asthma AR-Allergic } \\
\text { Rhinitis }\end{array}$ & $\begin{array}{c}\text { Raised Specific IgE to any of the } \\
\text { tested five food antigens }\end{array}$ & Maize \\
\hline 1. & 8 & M & BA & Soybean IgE (IU/ml) \\
\hline 2. & 9 & F & BA & 245.0 \\
\hline 3. & 12 & F & BA + AR & Peanut \\
\hline 4. & 12 & F & BA + AR & Peanut \\
\hline 5. & 15 & M & BA & Maize \\
\hline
\end{tabular}

against the commonly consumed five food antigens as stated earlier. The criteria for differentiating food sensitized cases was based on the ELISA OD value of $\geq 3$ times the mean value of healthy volunteers (cutoff point) against respective food extracts. Amongst the five, a cutoff point at OD's 0.13 for soybean estimated as described in Table 3 . The higher number of foods sensitized cases (14) is recorded for maize and chickpea, followed by peanut (12), and lowest in rice and soybean with 10 cases each. Thus, a total of $n=60$ cases of food sensitized (24\%), out of 252 have been recorded based on raised level of IgE to respective foods. Amongst these 60 cases, it was observed that the same 11 patients showed multiple sensitization to 2 or more number of foods, while 33 patients were recorded with raised IgE to single food antigen. Thus, it is interpreted that an aggregate of $44(11+33)$ sera reflecting $17 \%$ of total patients were observed as sensitized to one or more number of foods died. Amongst the 44 food sensitized cases observed, male accounted $60 \%$ (26 cases) and females as $40 \%$ (18 cases) respectively (Supplementary Table 1 ). 


\begin{tabular}{|c|c|c|c|c|c|}
\hline 6. & 17 & M & AR & Peanut & 150.0 \\
\hline 7. & 20 & M & $\begin{array}{l}\text { AR, Oral allergy syndrome (OAS) Throat Infection to } \\
\text { tomato, spices, cheese }\end{array}$ & Peanut, Soybean, Maize, Chickpea & 42.0 \\
\hline 8. & 20 & M & $\mathrm{BA}$ & Chickpea & 75.0 \\
\hline 9. & 22 & M & $\mathrm{BA}+\mathrm{AR}$ & Chickpea & 375.0 \\
\hline 10. & 23 & $\mathrm{~F}$ & AR & Maize & 750.0 \\
\hline 11. & 24 & M & BA & Chickpea & 698.0 \\
\hline 12. & 24 & $\mathrm{~F}$ & $\mathrm{BA}+\mathrm{AR}$ & Peanut, Rice, Chickpea & 845.0 \\
\hline 13. & 27 & M & Urticaria & Chickpea & 42.0 \\
\hline 14. & 27 & $\mathrm{~F}$ & $\mathrm{BA}+\mathrm{AR}$ & Chickpea & 291.6 \\
\hline 15. & 28 & M & $\mathrm{BA}+\mathrm{AR}$ & Soybean & 83.0 \\
\hline 16. & 29 & M & $\mathrm{BA}+\mathrm{AR}$ & Rice & 250.0 \\
\hline 17. & 30 & M & $\mathrm{BA}$ & Soybean, Rice, Chickpea & 166.6 \\
\hline 18. & 30 & $\mathrm{~F}$ & $\mathrm{BA}$ & Chickpea & 166.0 \\
\hline 19. & 32 & M & $\mathrm{BA}+\mathrm{AR}$ & Soybean, Chickpea, Maize & 741.0 \\
\hline 20. & 33 & M & $\mathrm{BA}$ & Peanut & 666.0 \\
\hline 21. & 34 & M & $\mathrm{BA}$ & Maize, Rice & 250.0 \\
\hline 22. & 34 & $\mathrm{~F}$ & $\mathrm{BA}+\mathrm{AR}$ & Chickpea & 104.0 \\
\hline 23. & 35 & $\mathrm{~F}$ & $\mathrm{BA}$ & Maize & 328.0 \\
\hline 24. & 35 & M & $\mathrm{BA}+\mathrm{AR}$ & Maize, Chickpea & 1125.0 \\
\hline 25. & 36 & $\mathrm{~F}$ & $\mathrm{BA}$ & Rice & 209.0 \\
\hline 26. & 36 & M & $\mathrm{BA}+\mathrm{AR}$ & Maize & 729.0 \\
\hline 27. & 38 & $\mathrm{~F}$ & AR & Peanut, Rice & 458.0 \\
\hline 28. & 42 & $\mathrm{~F}$ & $\mathrm{BA}+\mathrm{AR}$ & Maize & 84.0 \\
\hline 29. & 43 & $\mathrm{~F}$ & $\mathrm{BA}+\mathrm{AR}$ & Maize, Rice & 596.0 \\
\hline 30. & 45 & M & $\mathrm{BA}+\mathrm{AR}$ & Maize & 312.0 \\
\hline 31. & 45 & M & AR, Atopic dermatitis, Food allergy & Maize & 673.0 \\
\hline 32. & 47 & $\mathrm{~F}$ & $\mathrm{BA}+\mathrm{AR}$ & Peanut, Maize, Rice, Chickpea & 291.0 \\
\hline 33. & 49 & $\mathrm{~F}$ & BA & Peanut, Soybean, Rice & 291.0 \\
\hline 34. & 50 & $\mathrm{~F}$ & BA & Peanut & 533.0 \\
\hline 35. & 50 & M & $\mathrm{BA}+\mathrm{AR}$ & Chickpea & 750.0 \\
\hline 36. & 52 & $\mathrm{~F}$ & $\mathrm{BA}+\mathrm{AR}$ & Maize & 104.16 \\
\hline 37. & 53 & M & AR & Soybean & 563.0 \\
\hline 38. & 54 & M & $\mathrm{BA}+\mathrm{AR}$ & Peanut, Soybean & 895.0 \\
\hline 39. & 54 & M & AR, Food allergy & Maize & 520.0 \\
\hline 40. & 55 & $\mathrm{~F}$ & $\mathrm{BA}+\mathrm{AR}$ & Soybean & 121.0 \\
\hline 41. & 56 & $\mathrm{M}$ & AR & Soybean & 1500.0 \\
\hline 42. & 60 & M & AR, Urticaria, OAS & Rice & 150.0 \\
\hline 43. & 60 & M & AR & Peanut & 96.0 \\
\hline 44. & 60 & M & AR & Soybean & 79.0 \\
\hline
\end{tabular}

\section{Protein profile of Water Soluble Food Antigens}

The peanut antigen resolved into 15 protein bands of the range $64-10 \mathrm{kD}$. In soybean, the protein extract separated into 18 protein fractions in the range of $81-11 \mathrm{kD}$. Similarly, the protein extract of chickpea is observed to be separated into 16 protein fractions of the range $83-10 \mathrm{kD}$. In case of cereals, as rice fifteen protein fractions in the range $95-7 \mathrm{kD}$ are observed while the SDS-PAGE resolved profile of maize reflected eleven protein fractions in the range of $152-10 \mathrm{kD}$ (Figure 3).

Identification of IgE Binding Protein Fractions in different Food Antigens using sera of Selected Food Sensitized Patients by Immunoblot Assay

Out of the recorded 60 food sensitized cases, a limited number of three- five cases were finalized as per the availability 
of patient's sera for Immunoblot against respective food antigen(s).

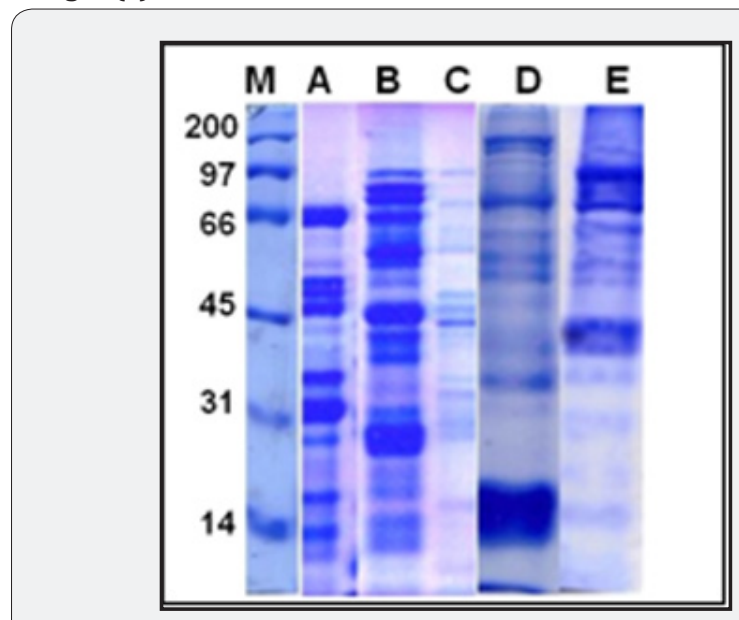

Figure 3: A $12 \%$ SDS-PAGE based protein profile of food antigens.

$$
\begin{array}{llc}
\text { M-Marker }(\mathrm{kD}) & \text { A-Peanut } & \text { B-Soybean } \\
\text { C-Chickpea } & \text { D-Rice } & \text { E-Maize }
\end{array}
$$

Peanut: Out of 12 peanut sensitized cases observed, three cases with specific IgE OD values as $0.4,0.21$ and 0.13 were proceeded for Immunoblot. Of these three, one of the cases was SPT positive to peanut. The same sera were recorded for IgE binding at two protein fractions of 37 and $32 \mathrm{kD}$ (Figure 4A).

Soybean: Of the 10 cases observed as positive in ELISA against soybean, three cases showing specific IgE OD values as $0.36,0.16$ and 0.15 were selected for Immunoassay. A single protein fraction of $30 \mathrm{kD}$ is detected as IgE binding by only one of the three selected sera samples (Figure 4B).

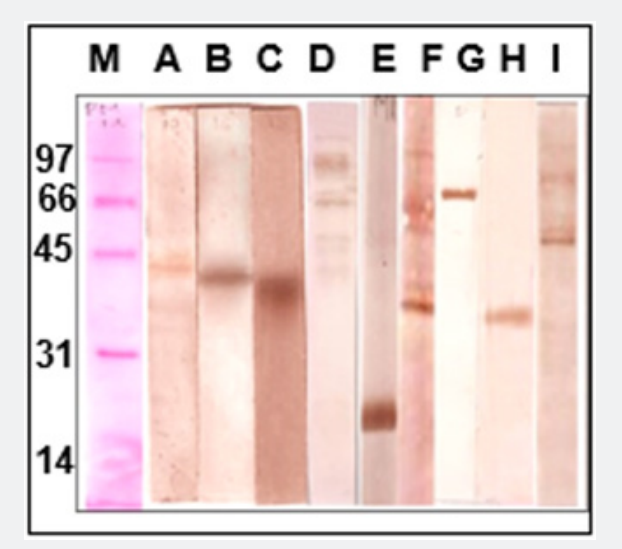

Figure 4: Immunoblot profile of selected food sensitized cases against different food antigens reveal a diversified range of $\lg E$ binding food protein fractions.
M-Marker (kD) A-Peanut
C-Chickpea
D -Rice

$$
\text { B -Soybean }
$$$$
\text { E-I -Maize }
$$

Chickpea: Out of 14 chickpea sensitized cases observed, three cases with OD values as $0.49,0.29$ and 0.12 were used for Immunoblot analysis. Of three, only one of the sera is observed with IgE binding to protein fraction of $32 \mathrm{kD}$ (Figure 4C).
Rice: Out of 10 rice sensitized cases, only two cases with OD values as 0.7 and 0.2 were selected for Immunoblot assay due to limited availability of sera. Of which, one sera with clinical symptoms and SPT positivity to rice detected six IgE binding protein fractions of 73, 62,55, 51,39 and $29 \mathrm{kD}$ (Figure 4D).

Maize: Of the 14 positive cases observed in ELISA, five cases with high OD values as $0.8,0.420 .36,0.27$ and 0.2 were selected for Immunoblot analysis, as these were reported with SPT positivity to maize and history of food allergy. One case showed a prominent smear of $\sim 28 \mathrm{kD}$ while with the other sera with food allergy showed protein fractions of 41 and $48 \mathrm{kD}$ as IgE binding. Protein fractions at 78 and $33 \mathrm{kD}$ were also recognized as IgE binding by two other sensitized cases individually. The fifth case detected protein fractions of 41, 48, 68 and $88 \mathrm{kD}$ as IgE binding (Figure $4 \mathrm{E}-\mathrm{I}$ ).

\section{Discussion}

The diagnostic role of total IgE is limited to atopy irrespective of clinical history or allergen exposure and gives no clue to the sensitizing allergen profile of an individual [20]. A broader reference range of total IgE for normal population as $1.5-677 \mathrm{kU} / \mathrm{L}$ depending on the various ethnic backgrounds and geographic locations have been reported $[4,5]$. In one of the studies on Indian patients, different values for total serum IgE have been reported as $229 \mathrm{kU} / \mathrm{ml}$ for asymptomatic cases, $363 \mathrm{kU} / \mathrm{ml}$ for questionnaire diagnosed asthmatics and $489 \mathrm{kU} /$ $\mathrm{ml}$ for physician diagnosed symptomatic asthmatics [21]. In another study a cutoff point as $200 \mathrm{IU} / \mathrm{ml}$ has been suggested for defining atopicity [4]. In the present study, the mean total serum IgE level in the symptomatic group (AR, Asthma + AR, and only asthma) is recorded to be significantly higher $(\mathrm{p}<0.001)$ as compared to control subjects. The same has been observed in various other populations [4,21]. We also analyzed the percentage of atopic cases in the patient participants as per the suggested cutoff-point [4].

As per the outlined criteria of atopy in an earlier study on Indian patients [4], it was analyzed that of the 252 sera screened, 154 (61\%) were classified as atopic while 98 (39\%) had IgE levels lower than $200 \mathrm{IU} / \mathrm{ml}$, although symptomatic along with overlapping of the recorded values with healthy subjects. These cases may be misdiagnosed for not being "atopic" but symptomatic. Thus, indicating the limited but usefulness of total serum IgE values in categorizing atopy in present patients' population as also described by others $[4,6]$. An atopic case may develop respiratory disorder while a clinically proven respiratory disorder patient may not have elevated serum IgE levels to be called as atopic. It is also indicated that solely total serum IgE is insufficient to define atopicity and both these parameters may behave independently [6].

A number of studies involving estimation of Total IgE have reported significant differences in the serum IgE levels between male and female patients of allergy/ asthma $[4,5,7]$. While few 


\section{Global Journal of Otolaryngology}

studies have reported for comparable IgE levels in both the sex groups [22,23]. We did not observe statistically significant difference in the IgE levels based on gender in the diseased groups $[22,23]$. The methodology adopted, enrolled population sample size and the study center are the variable and influencing factors with respect to every study. In the present study we have participants enrolled from two major cities of North India and the sample size was also relatively low. We would highlight the fact that at the present time, an increasing number of women are also now working professionals moving out of the confines of home. Women are thus also exposed to a greater number of outdoor allergens and may exhibit similar level of total serum IgE as exhibited by males.

Studies have even reported for elevated level of IgE in the younger age groups than adults $[6,7,23]$ whereas few studies have highlighted for uncertainty for a regular pattern in IgE levels $[4,24]$. We have analyzed the association of Total IgE with the age of the allergic patients. Higher total serum IgE level was recorded in the childhood group while the minimum was observed in the older age group. The level of total IgE in the rest four age groups ranging from 13-50yrs reflected a stable yet declining pattern. Overall, with increasing age, total serum IgE was observed to be decreasing but the variation was statistically not significant $(\mathrm{p}>0.05)$. The present findings are only partially in agreement with earlier observations $[6,7,23]$. An IgE-mediated food allergy requires both the presence of sensitization and the development of symptoms on exposure to a specific food [9]. The prevalence of perceived food hypersensitivity in adults, regardless of the underlying mechanism has been estimated, at $11 \%$ to $21 \%$ [25,26]. Food sensitization (SPT positive or raised specific IgE) is reported to be highly prevalent in atopic (25\%) than in general population [12]. Single as well as multiple food sensitization on the basis of sIgE have been described in few of the population studies $[12,25,26]$. An insight into the prevalence of food specific IgE sensitization patterns is important to predict the at-risk population.

In a vast country like India, population based studies focused on estimation of food sensitization pattern are limited and more centered around foods such as egg, chickpea, rice etc. [12,27]. Kumar et al. [12] have estimated for true IgE mediated food allergy as $4.5 \%$ while multiple food sensitization as $11 \%$. In the present study on the basis of specific IgE titre to different food antigens, the overall prevalence of food sensitization was estimated to be $17 \%$ among the enrolled respiratory allergic patients. Specific IgE positivity to single food antigen was recorded in $12 \%$ of the total population which is in accordance with the earlier reports [25,26]. Multiple food sensitization is reflected amongst $4.7 \%$ of the entire symptomatic group, which is similar to earlier observations [26]. The Big eight foods are responsible for majority of the food allergic reactions [9]. In our present analysis, cereals and legumes were contributed equally to the prevalence pattern (4.8\%). These findings are also supported with reference to an earlier Indian study highlighting for diversified foods such as rice, citrus fruits, black gram etc. as common offending food allergens [12].

Unlike, many studies, reporting for the strong association of food sensitization with asthma $[12,26]$, we analyzed that amongst the total food sensitized cases, asthma and rhinitis are equally distributed. We would also like to highlight the fact that among the sensitized cases, four cases are of definite food allergy correlating with their clinical symptoms. Of these four, only three have been classified as atopic in this study. The levels of total IgE might be viewed as diagnostically less informative than levels of allergen-specific IgE, instead measuring data on both markers of atopy can be beneficial [7]. A step further in the study, of these foods sensitized cases, three sera samples for each of the food antigens were analyzed for Immunoblotting, so as to rule out for the possibility to what extent these foods sensitized (suspected) cases may be truly IgE mediated food allergy cases. Out of the three suspected peanut sensitized sera screened for elucidation of $\operatorname{IgE}$ binding epitopes of peanut, a single patients serum recognized two peanut protein fractions of 37 and $32 \mathrm{kD}$ as IgE binding. Peanut protein fractions of 38-49 are indicated to be of acidic arachin group, which have been extensively reported of constituting the major peanut allergen Ara h 3 [28]. The 37 $\mathrm{kD}$ protein fraction in crude peanut extract has been reported to share cross reactivity with other legumes in Indian atopic patients [13]. Of the patient's sera screened against soybean, a single case identified a $30 \mathrm{kD}$ protein fraction as immunoreactive which may be described as amongst the reported major allergens of soybean [29]. The same group have reported $68 \mathrm{kD}$ (Gly m bd $68 \mathrm{k}$ ) and $30 \mathrm{kD}$ (Gly $\mathrm{m}$ bd $30 \mathrm{~K}$ ) as $\alpha$ - the subunit of $\beta$ conglycinin and the $30 \mathrm{kD}$ as oil body associated protein. With respect to chickpea, a single patient serum is observed with IgE binding at $32 \mathrm{kD}$ which may be interpreted similar to a $35 \mathrm{kD}$ reported major allergen using sera of suspected Indian food allergy cases [30].

For rice, 6 protein fractions in the range of 73 - $29 \mathrm{kD}$ were observed as IgE binding by single patients' sera which is also SPT positive to rice. The present findings reconfirm protein fractions of 62,55 and $39 \mathrm{kD}$ as IgE binding, as per an earlier study on Indian patients [31]. Literature suggests for unavailability of information on characterization of the stated potential rice allergenic proteins while rice allergens of 14-16, 26 and $33 \mathrm{kD}$ have been identified as $\alpha$-amylase inhibitors, $\alpha$-globulin and glyoxylase respectively [32,33]. With respect to maize, using five of the sensitized sera, seven protein fractions in the range $88-28 \mathrm{kD}$ are recognized as immunoreactive. Of these 7 IgE binding proteins, it is suspected that 4 mid to low molecular weight range proteins of $28-48 \mathrm{kD}$ could possibly be classified belonging to zeins and other three of higher molecular weight could be categorized as vicilin $[34,35]$. This is a preliminary postulation as to the best of our information there is no study on elucidation of maize allergens using sera of Indian atopic patients. Thus, the recorded food sensitized cases, irrespective of history of clinical allergy or being atopic (SPT or IgE based) 
still revealed IgE binding to the food antigens. Even few of the food allergic cases among these foods sensitized cases could not show IgE binding. This may be explained as these cases are of respiratory disorders which must have been exposed to other environmental factors that have resulted in cross reactivity of pollen allergens (aeroallergens) and food allergens (class-II) via the respiratory tract in an individual leading to a positive immunoreactive profile. Galvin et al. showed that by using a predictive model based on 6 parameters, SPT, serum foodspecific IgE, total IgE, symptom history, sex, and age, they could calculate the likelihood of reactions ( $97 \%$ accuracy) or tolerance (94\% accuracy) to peanut, milk, and egg better than with individual parameters [35].

\section{Conclusion}

Serum IgE is the clinical marker for allergy diagnosis but it seems to have limitations to atopy only. Elevated serum IgE levels appears to be associated with male sex and the younger age group. This study also looked at the prevalence of food sensitization in Indian atopic patients against five commonly consumed cereal and legumes. An increase in prevalence of food sensitization as compared to earlier reports in indicated. Cereals and legumes are observed to be equal sensitizers in respiratory allergy patients of North India. Atopy, asthma and elevated serum IgE level are observed to be partially associated factors for food sensitization.

\section{References}

1. Cookson W (1999) The alliance of genes and environment in asthma and allergy. Nature 25: 5-11.

2. Pawankar R, Canonica GW, Holgate ST, Lockey RF (2011) The WAO white book on allergy. World Allergy Organization.

3. Yunginger JW (1988) Clinical significance of IgE. In: Middleton E, Reed CE, Ellis EF, Adkinson NF, Yunginger JW, editors. Allergy: Principles and Practices. St Louis, MO: CV Mosby pp. 849-860.

4. Sharma S, Kathuria PC, Gupta CK, Nordling K, Ghosh B, et al. (2006) Total serum immunoglobulin E levels in a case-control study in asthmatic/allergic patients, their family members, and healthy subjects from India. Clin Exp Allergy 36(8): 1019-1027.

5. Ezeamuzie CI, Ali-Ali SF, Al- Dowaisan A, Khan M, Hijazi Z, et al. (1999) Reference values of total serum IgE and their significance in the diagnosis of allergy among the young adult Kuwaiti population. Clin Exp Allergy 29(3): 375-381.

6. Burney P, Malmberg E, Chinn S, Jarvis D, Luczynska C, et al. (1997) The distribution of total and specific serum IgE in the European Community Respiratory Health Survey. J Allergy Clin Immunol 99(3): 314-322.

7. Salo PM, Calatroni A, Gergen PJ, Hoppin JA, Sever ML, et al. (2011) Allergy-related outcomes in relation to serum IgE: results from the National Health and Nutrition Examination Survey 2005-2006. J Allergy Clin Immunol 127(5): 1226-1235.

8. Sicherer SH, Sampson HA (2014) Food allergy: Epidemiology, pathogenesis, diagnosis, and treatment. J Allergy Clin Immunol 133(2): 291307.

9. Burks AW, Tang M, Sicherer S, Muraro A, Eigenmann PA, et al. (2012) International Consensus on Food Allergy. J Allergy Clin Immunol 129: 906-920.
10. Corinne A K, Robert AW, Elizabeth CM (2012) Limitations of reliance on specific IgE for epidemiologic surveillance of food allergy. J Allergy Clin Immunol 130: 1207- 1209.

11. Gupta SK (1996) Clinical profile of bronchial asthma in Eastern India. A prospective analysis of 7208 patients. Lung India 14(2): 60-65.

12. Kumar R, Kumari D, Srivastava P, Khare V, Fakhr H, et al. (2010) Identification of IgE-mediated food allergy and allergens in older Children and adults with asthma and allergic rhinitis. Indian J Chest Dis Allied Sci 52(4): 217-224.

13. Kasera R, Singh BP, Lavasa S, Prasad KN, Sahoo RC, et al. (2011) Kidney Bean: A Major sensitizer among legumes in asthma and rhinitis patients from India. PLoS ONE 6(11): e27193.

14. Bousquet J, Cauwenberge PV, Khaltaev N (2001) Allergic rhinitis and its impact on Asthma. J Allergy Clin Immunol 108: S147-334.

15. American Thoracic Society (1991) Lung Function Testing: selection of reference values and interpretative strategies. Am Rev Respir Dis 144(5): 1202-1218.

16. Sepulveda R, Longbottom JL, Pepys J (1979) Enzyme linked immunosorbent assay (ELISA) for IgG and IgE antibodies to protein and polysaccharides antigens of Aspergillus fumigatus. Clin Allergy 9(4): 359371.

17. Lammeli UK (1970) Cleavage of structural proteins during the assembly of the head of the bacteriophage T4. Nature 227: 680-685.

18. Towbin H, Staehelin T, Gordon J (1979) Electrophoretic transfer of proteins from polyacrylamide gels to nitrocellulose sheets: procedure and some applications. Proc Natl Acad Sci 76(9): 4350-4354.

19. Mishra A, Gaur SN, Singh BP, Arora N (2012) In silico assessment of the potential allergenicity of transgenes used for the development of GM food crops. Food and Chemical Toxicology 50(5): 1334-1339.

20. Amarasekera M (2011) Immunoglobulin E in health and disease. Asia Pac Allergy 1: 12-15.

21. Chowgule RV, Shetye VM, Parmar JR, Bhosale AM, Khandagale MR, et al. (1998) Prevalence of respiratory symptoms, bronchial hyperreactivity, and asthma in a megacity. Results of the European community respiratory health survey in Mumbai (Bombay). Am J Respir Crit Care Med 158(2): 547-554.

22. Chew FT, Lim SH, Goh DYT, Lee BW (1999) Sensitization to local dust mite fauna in Singapore. Allergy 54(11): 1150-1159.

23. Borrish L, Chipps B, Deniz Y, Gujrathi S, Zheng B, et al. (2005) Total serum IgE levels in a large cohort of patients with severe or difficult-to-treat asthma. Annals of Allergy, Asthma \& Immunology 95(3): 247-253.

24. Kerkhof M, Dubois AE, Postma DS, Schouten JP, de Monchy JG (2003) Role and interpretation of total serum IgE measurements in the diagnosis of allergic airway disease in adults. Allergy 58(9): 905-911.

25. Patelis A, Gunnbjornsdottir M, Borres MP, Burney P, Gislason T, et al. (2014) Natural history of perceived food hypersensitivity and IgE sensitization to food allergens in a cohort of adults. PLoS ONE 9(1): e85333.

26. Liu AH, Jaramillo R, Sicherer SH, Wood RA, Bock SA, et al. (2010) National prevalence and risk factors for food allergy and relationship to asthma: results from the National Health and Nutrition Examination Survey 2005-2006. J Allergy Clin Immunol 126(4): 798-806.

27. Misra A, Prasad R, Das M, Dwivedi PD (2008) Prevalence of legume sensitization in patients with naso-bronchial allergy. Immunopharmacol Immunotoxicol 30(3): 529-542.

28. Rabjohn P, Helm EM, Stanley JS, West CM, Sampson HA, et al. (1999) Molecular cloning and epitope analysis of the peanut allergen Ara h 3. J Clin Invest 103(4): 535-542. 
29. Ogawa T, Bando N, Tsuji H, Nishikawa K, Kitamura K (1995) Alpha-subunit of beta-conglycinin, an allergenic protein recognized by IgE antibodies of soybean-sensitive patients with atopic dermatitis. Biosci Biotechnol Biochem 59(5): 831-833.

30. Patil SP, Niphadkar PV, Bapat MM (2001) Chickpea a major food allergen in the Indian subcontinent and its clinical and immunochemical correlation. Ann Allergy Asthma Immunol 87(2): 140-145.

31. Kumar R, Srivastava P, Kumari D, Fakhr H, Sridhara S, et al. (2007) Rice (Oryza sativa) allergy in rhinitis and asthma patients: a clinico-immunological study. Immunobiology 212(2): 141-147.

32. Usui Y, Nakase M, Hotta H, Urisu A, Aoki N, et al. (2001) A 33-kDa allergen from rice (Oryza sativa L japonica). cDNA cloning, expression, and identification as a novel glyoxalase I. J Biol Chem 276(14): 1137631181.

33. Pasini G, Simonato B, Curioni A, Vincenzi S, Cristaudo A, et al. (2002) IgE-mediated allergy to corn: $50 \mathrm{kDa}$ protein, belonging to the reduced soluble proteins, is a major allergen. Allergy 57(2): 98-106.

34. Fasoli E, Pastorello EA, Farioli L, Scibilia J, Aldini G, et al. (2009) Searching for allergens in maize kernels via proteomic tools. J Proteomics 72(3): 501-510.

35. Dunn Galvin A, Daly D, Cullinane C, Stenke E, Keeton D, et al. (2011) Highly accurate prediction of food challenge outcome using routinely available clinical data. J Allergy Clin Immunol 127(3): 633-639.

This work is licensed under Creative Commons Attribution 4.0 License

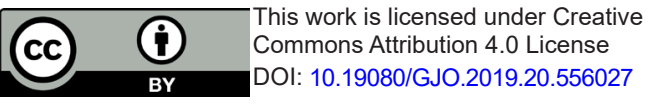

Your next submission with Juniper Publishers will reach you the below assets

- Quality Editorial service

- Swift Peer Review

- Reprints availability

- E-prints Service

- Manuscript Podcast for convenient understanding

- Global attainment for your research

- Manuscript accessibility in different formats

( Pdf, E-pub, Full Text, Audio)

- Unceasing customer service

Track the below URL for one-step submission https://juniperpublishers.com/online-submission.php 